\title{
ANALISIS TERHADAP PERKARA PRAPERADILAN \\ YANG TIDAK DINYATAKAN GUGUR SESUAI PUTUSAN MAKHAMAH KONSTITUSI
}

\author{
Fransina Pattiruhu \\ Staf Pengajar Fakultas Hukum Universitas Kristen Artha Wacana Kupang \\ NTT, Indonesia \\ Email:fransinglory@gmail.com \\ Salmun Adu \\ Staf Pengajar Fakultas Hukum Universitas Kristen Artha Wacana Kupang \\ NTT, Indonesia \\ Email:salmunsaul.adu@gmail.com

\section{Jeremia Alexander Wewo} \\ Staf Pengajar Fakultas Hukum Universitas Kristen Artha Wacana Kupang \\ NTT, Indonesia \\ Email:jeremiawewo92@gmail.com
}

\begin{abstract}
Abstrak
Penelitian ini bertujuan untuk mengetahui dan menganalisis mengapa permohonan praperadilan dengan Nomor Perkara 3/Pid.Pra/2017/PN.Kfm tidak digugurkan sesuai dengan Putusan Makhamah Konstitusi Nomor 102/PUU-XIII/2015 jo Pasal 82 ayat (1) huruf (d) Kitab Undang-Undang Hukum Acara Pidana (KUHAP). Penelitian ini menggunakan metode penelitian hukum normatif atau doktrinal yang berfokus pada pendekatan Undang-undang, pendekatan konsep, dan pendekatan kasus. Dalam penelitian ditemukan, bahwa terdapat perbedaan penafsiran terhadap norma-norma hukum positif sehingga dapat menimbulkan ketidakpastian hukum baik kepada penegak hukum maupun pelaksana hukum itu sendiri. Saran yang diberikan oleh penulis ialah diharapkan para penegak hukum dalam menafsirkan norma hukum seyogiannya lebih mencermati makna dari norma-norma tersebut serta memperhatikan korelasi antara norma-norma yang saling berhubungan sehingga tidak terjadi perbedaan penafsiran dalam menegakkan hukum.
\end{abstract}

\section{Kata Kunci: Praperadilan; Penafsiran; Penegakkan Hukum}

\begin{abstract}
This research aims to know and analyze why the application of pretrial with Case number 3/ Pid. Pra/2017/PN. KFM is not aborted in accordance with the ruling of the Constitutional Decree No. 102/PUU-XIII/2015 Jo Article 82 paragraph (1) ofletter (d) Criminal Program Law Act (KUHAP). This research uses normative or doctrinal legal research methods that focus on the ACT approach, concept approach, and case approach. In the study found, that there was a discrepancy interpretation of positive legal norms that could lead to legal uncertainty either to law enforcement or the implementing law itself. The advice given by the author is expected that law enforcement officials interpret the legal norms to pay more attention to the meaning of these norms and to observe the correlation between interconnected norms so that they do not occur Differences in interpretation in enforcing the law.
\end{abstract}

\section{Keywords: Pretrial; Interpretation; Law Enforcement}




\section{A. PENDAHULUAN}

Negara Indonesia menganut paham demokrasi dan nomokrasi. Landasan yuridis sebagai negara demokrasi tercantum dalam Pasal 1 ayat (2) Undang-Undang Dasar Negara Republik Indonesia Tahun 1945 yang berbunyi "kedaulatan berada di tangan rakyat dan dilaksanakan menurut Undang-Undang Dasar". ${ }^{1}$ Berpijak pada landasan konstitusi menunjukkan, bahwa Indonesia menganut paham kedaulatan rakyat yang merupakan kekuatan istimewa dan fundamentalnya demokrasi. Demokrasi yang sering diidentikan dengan jargon "pemerintahan dari rakyat, oleh rakyat, dan untuk rakyat, menunjukkan kalau kesejatian demokrasi adalah kedaulatan rakyat. Adapun paham nomokrasi dapat dibuktikan dengan merujuk ketentuan Pasal 1 ayat (3) Undang-Undang Dasar Negara Republik Indonesia Tahun 1945 yang menegaskan "negara Indonesia adalah negara hukum". Garis konstitusi inilah sebagai dasar paham kedaulatan hukum yang pada pokoknya menganut prinsip supremasi hukum. Artinya segala aspek kehidupan berbangsa dan bernegara harus merujuk pada hukum yang berlaku. ${ }^{2}$

Hukum bukan hanya sekedar merupakan petunjuk atau pedoman tingkah laku manusia dalam masyarakat, melainkan harus benar-benar hidup dalam masyarakat dengan tujuan agar ketertiban dan kedamaian dalam masyarakat dapat tercapai. Hukum sebagai suatu sistem norma untuk mencapai tujuan yang dikehendaki secara efektif. ${ }^{3}$ Selain itu, dilihat dari pendekatan normatif, hukum diasumsikan sebagai sesuatu yang otonom sehingga keberlakuannya ditentukan oleh hukum sendiri bukanlah faktor-faktor diluar hukum. Berdasarkan asumsi ini, hukum itu telah dianggap sempurna dan final tinggal dilaksanakan. Karena hukum itu adalah pedoman tingkah laku yang tidak boleh disimpangi karena hukum merupakan perintah dari yang berdaulat, maka apabila tidak dilaksanakan akan mendapatkan sanksi. ${ }^{4}$ Dengan pandangan ini, tujuan hukum yang ingin diwujudkan adalah kepastian hukum dan karenanya keberlakuannya disebut dengan keberlakuan yuridis. Oleh karena itu, hukum bertindak sebagai tuan dan masyarakat adalah pelayannya ${ }^{5}$, sehingga perilaku masyarakat harus tunduk pada hukum dan hukumlah yang berdaulat (supremacy of law). ${ }^{6}$

Pendekatan sosiologis, hukum itu diasumsikan sebagai sesuatu yang tidak otonom sehingga keberlakuannya ditentukan oleh faktor-faktor non yuridis, karena hukum sebagai gejala sosiologis adalah produk interaksi sosial (ekonomi, politik dan lain-lain). Dengan pandangan ini, tujuan hukum yang ingin diwujudkan adalah keadilan hukum. Artinya, hukum dipatuhi oleh masyarakat sehingga efektif berlaku karena hukum tersebut dianggap telah merupakan representasi dari rasa keadilan yang tumbuh dan berkembang di masyarakat. Akibatnya, hukum harus berubah mengikuti perubahan masyarakat. Jadi, posisi hukum itu adalah pelayan dan masyarakat (interaksi sosial) adalah tuannya.

Pendekatan filosofis, hukum itu otonom atau tidak otonom bukanlah merupakan isu sentral, karena yang penting adalah apakah hukum itu bermanfaat mewujudkan nilai-nilai keadilan dan kebenaran, terlepas apakah hukum merupakan output dari proses sosiologis empiris atau

${ }^{1}$ Bambang Satriya, Urgensi Integritas Penyelenggara Pemilihan Umum dalam Menegakkan Kedaulatan Rakyat, "Jurnal Etika dan Pemilu", Vol.3, No. 1, 2017, 9-20, hlm.10.

${ }^{2}$ Jeremia Alexander Wewo, Kotan Y. Stefanus, and Umbu Lili Pekuwali , Code Of Ethics Urgency In The Implementation Of General Election In Indonesia, "Jurnal Dinamika Hukum, Faculty Of Law Universitas Jenderal Soedirman”, Vol.18, No.2, 2018, 194-199, hlm.194

${ }^{3}$ Sri Mulyani, Penyelesaian Perkara Tindak Pidana Ringan menurut Undang-Undang dalam Perspektif Restoratif Justice, “Jurnal De Jure", Vol.16, No.3, 2016, 337-351, hlm.342.

${ }^{4}$ Zulfadli Barus, Analisis Filosofis tentang Peta Konseptual Penelitian Hukum Normatif dan Penelitian Hukum Sosiologis, “Jurnal Dinamika Hukum, Faculty of Law Universitas Jenderal Soedirman”, Vol.13, No. 2, 2013, 307-318, hlm. .311.

${ }^{5}$ Misahardi Wilamarta dan Zulfadli Barus, Manfaat Analisis Yuridis dan Sosiologis yang Bersifat Komplementer dalam Perjanjian Kredit untuk Meminimalisir Resiko Bank sebagai Kreditor, “Jurnal Hukum Yustisia”, Vol 1, No.2, 2012, 151-168, hlm.154.

${ }^{6}$ Loc.cit 
output dari proses yuridis rasional. Bila hukum tidak merupakan cerminan nilai-nilai keadilan dan kebenaran, maka hukum tersebut tidak memiliki legitimasi filosofis. Artinya, hukum yang seperti itu tidak wajib dipatuhi karena ia telah kehilangan dasar mengikat. Dengan pandangan ini, tujuan yang ingin dicapai adalah kemanfaatan dalam arti keseimbangan antara kebenaran (kepastian hukum) yang bersifat yuridis rasional dengan keadilan (keadilan hukum) yang bersifat sosiologis empiris. Ini seperti timbangan yang merupakan simbol hukum. ${ }^{7}$

Undang-undang Nomor 8 Tahun 1981 tentang Hukum Acara Pidana memuat prinsipprinsip atau asas hukum, diantaranya prinsip legalitas, prinsip keseimbangan, asas praduga tidak bersalah, prinsip pembatasan penahanan, asas ganti rugi dan rehabilitasi, penggabungan pidana dan tuntutan ganti rugi, asas unifikasi, prinsip diferensiasi fungsional, prinsip saling koordinasi, asas keadilan sederhana, cepat, dan biaya ringan, dan prinsip peradilan terbuka untuk umum. ${ }^{8}$ Pemuatan prinsip-prinsip hukum (the principle of law) tersebut dalam Kitab Undang-Undang Hukum Acara Pidana tidak lain untuk menjamin penegakan hukum dan hak asasi manusia yang telah digariskan baik dalam landasan konstitusional maupun dalam Undang-Undang Nomor 39 Tahun 1999 tentang Hak Asasi Manusia. Pengaturan perlindungan hak asasi dalam wilayah/konteks penegakan hukum ditegaskan dalam Pasal 28D ayat (1) Undang-Undang Dasar Negara Republik Indonesia Tahun 1945 "setiap orang berhak atas pengakuan, jaminan, perlindungan, dan kepastian hukum yang adil serta perlakukan yang sama di hadapan hukum". ${ }^{\circ}$

Sebagai negara yang berdasar atas hukum, harus konsisten menerapkan praperadilan sebagai lembaga pengawasan horizontal oleh pengadilan negeri yang tidak setengah hati terhadap kinerja kepolisian dan kejaksaan. ${ }^{10}$ Praperadilan merupakan satu mekanisme hukum acara pidana yang dapat ditempuh untuk menguji keabsahan tindakan aparat penegak hukum. ${ }^{11}$ Pengujian keabsahan penggunaan wewenang oleh aparat penegak hukum baik penyidik maupun penuntut umum sebagai upaya koreksi terhadap penggunaan wewenang apabila dilaksanakan secara sewenang-wenang dengan maksud/tujuan lain dari yang dilakukan secara tegas dalam KUHAP guna menjamin perlindungan terhadap hak asasi setiap orang termasuk dalam hal ini pemohon. $^{12}$

Praperadilan merupakan hal baru dalam dunia Peradilan Indonesia yang diperkenalkan oleh Kitab Undang-Undang Hukum Acara Pidana (KUHAP) dalam kehidupan penegakkan hukum. Posisi praperadilan dalam Kitab Undang-Undang Hukum Acara Pidana terdapat dalam Bab X bagian kesatu serta yang memiliki yurisdiksi ialah Pengadilan Negeri. ${ }^{13}$ Prosedur pengajuan praperadilan di Pengadilan Negeri dilakukan dengan membuat permohonan kepada Ketua Pengadilan Negeri untuk nantinya diregister dalam register khusus tentang praperadilan. Dari permohonan tersebut, sesuai ketentuan Pasal 78 ayat (2) Kitab Undang-Undang Hukum Acara Pidana (KUHAP), Ketua Pengadilan Negeri akan menunjuk seorang hakim tunggal untuk memeriksa perkara praperadilan dengan dibantu oleh seorang panitera untuk penetapan hari

\footnotetext{
${ }^{7}$ Ibid.

${ }^{8}$ Hardianto Djanggih dan Yusuf Saefuddin, Pertimbangan Hakim Pada Putusan Praperadilan: Studi Putusan Nomor: 09/Pid.Pra/2016/Pn.Lwk Tentang Penghentian Penyidikan Tindak Pidana Politik Uang, "Jurnal Penelitian Hukum De Jure”, Vol. 17, No. 3, 2017, 413-245, hlm.414.

${ }^{9}$ Arri Djami “Analisis Yuridis Terhadap Putusan Hakim Praperadilan Tentang Keabsahan Tindakan Penyitaan Oleh Penyidik Pegawai Negeri Sipil Kehutanan (Studi Kasus Putusan Praperadilan Pontianak dan Bengkayang), “Jurnal Nestor Magister Hukum", Vol.2 , No.2, 2012, 1-18, hlm.2.

${ }^{10}$ Sujiono, Implementasi Lembaga Praperadilan Untuk Perlindungan Hukum Hak-Hak Tersangka (Studi Kasus di Pengadilan Negeri Tenggarong, “Jurnal Arena Hukum”, Vol.6, No.2, 2013, 272-289, hlm.274.

${ }^{11}$ Fachrizal Afandi, Perbandingan Praktek Praperadilan Dan Pembentukan Hakim Pemeriksa Pendahuluan Dalam Peradilan Pidana Indonesia, “Jurnal Mimbar Hukum”, Vol.16, No.1, 2016, 93-106, hlm.96.

${ }^{12}$ Yusi Amdani, Implikasi Penafsiran Undang-Undang oleh Hakim Praperadilan dalam Perkara Tindak Pidana Korupsi, “Jurnal Mimbar Hukum”, Vol.27, No.3, 2015, 459-471, hlm.461.

${ }^{13}$ Sri Wulandari, Kajian tentang Praperadilan dalam Hukum Pidana, EJurnal Serat Acitya, Vol.4, No.3, 2015, 1-14, hlm.1.
} 
sidang. Pasal 82 ayat (1) huruf (c) Kitab Undang-Undang Hukum Acara Pidana (KUHAP) menyaratkan untuk segera bersidang 3 (tiga) hari setelah dicatat dalam register dan dalam tempo 7 (tujuh) hari perkara sudah harus dijatuhkan putusan. Sedangkan untuk pemanggilan para pihak dilakukan bersamaan dengan penetapan hari sidang oleh hakim yang ditunjuk serta tata cara maupun bentuk putusan dalam praperadilan tidak diatur dalam ketentuan khusus oleh Kitab Undang-Undang Hukum Acara Pidana (KUHAP).${ }^{14}$

Lembaga praperadilan di Indonesia mirip dengan lembaga Pretrial di Amerika Serikat, lembaga Rechter Commisaris di Belanda atau lembaga Judge d'Instruction di Perancis. ${ }^{15}$ Praperadilan merupakan kewenangan yang diberikan oleh undang-undang kepada hakim pengadilan negeri untuk melaksanakan fungsi-fungsi penilaian terhadap beberapa hal, antara lain: 1) sah atau tidaknya suatu penangkapan dan atau penahanan atas permintaan tersangka atau keluarganya atau pihak lain atas kuasa tersangka; 2) sah atau tidaknya penghentian penyidikan atau penghentian penuntutan atas permintaan demi tegaknya hukum dan keadilan; 3) permintaan ganti kerugian atau rehabilitasi oleh tersangka atau keluarganya atau pihak lain atas kuasanya yang perkaranya tidak diajukan pada pengadilan. ${ }^{16}$

Namun, pada April 2015 Mahkamah Konstitusi telah mengabulkan sebagian pengujian Undang-Undang Nomor 8 Tahun 1981 tentang Hukum Acara Pidana (KUHAP). Dalam Amar Putusan Mahkamah Konstitusi Nomor 21/PUU-XII/2014, Mahkamah Konstitusi telah menetapkan objek praperadilan baru yaitu mengenai sah atau tidaknya penetapan tersangka, penggeledahan dan penyitaan. Mahkamah Konstitusi menjadikan penetapan tersangka sebagai salah satu objek praperadilan yang sebelumnya tidak diatur dalam Kitab Undang-Undang Hukum Acara Pidana (KUHAP). Pasal 77 huruf(a) KitabUndang-Undang Hukum Acara Pidana dinyatakan inkonstitusional bersyarat sepanjang dimaknai termasuk penetapan tersangka, penggeledahan dan penyitaan. Selain itu, Mahkamah konstitusi juga menyatakan bahwa Pasal 77 Kitab Undang-Undang Hukum Acara Pidana (KUHAP) tidak mempunyai kekuatan hukum mengikat sepanjang tidak dimaknai mencakup sah atau tidaknya penetapan tersangka, penggeledahan dan penyitaan. Dengan kata lain, penetapan tersangka setelah dikeluarkannya Putusan Mahkamah Konstitusi mengenai sah atau tidaknya penetapan tersangka menjadi objek praperadilan, penggeledahan, penyitaan dan pemeriksaan surat, setelah putusan Mahkamah Konstitusi masuk dalam ruang lingkup praperadilan. ${ }^{17}$

Perkembangan selanjutnya terjadi lagi perubahan dalam pelaksanaan praperadilan. Praperadilan yang telah diatur dalam Kitab Undang-Undang Hukum Acara Pidana (KUHAP), didalamnya telah diberi ketentuan mengenai kapan praperadilan itu dinyatakan gugur. Praperadilan gugur ketika perkara sudah mulai diperiksa oleh Pengadilan Negeri, disaat pemeriksaan praperadilan belum selesai. Ketentuan mengenai kapan gugurnya praperadilan sesuai dengan ketentuan Kitab Undang-Undang Hukum Acara Pidana (KUHAP) ini diterapkan oleh para hakim tunggal di berbagai pemeriksaan praperadilan dengan penafsiran masing-masing hakim tunggal tersebut. ${ }^{18}$ Terkait ketidakjelasan mengenai waktu gugurnya praperadilan, pada

\footnotetext{
${ }^{14}$ Rahmad Efendy Al Amin Siregar, Due Process Of Law dalam Sistem Peradilan Pidana di Indonesia dalam kaitannya dengan Perlindungan HAM, “Jurnal Kajian Ilmu-Ilmu Keislaman, IAIN Padang Sidimpuan”, Vol.1, No.1, 2015, 35-46, hlm.44.

${ }^{15}$ Oktein Josephus Susak, Perspektif Keadilan Dan Kepastian Hukum Dalam Putusan Praperadilan Nomor: 04/Pid. Prap/2015/Pn.Jkt.Sel. Tahun 2015, “Jurnal Arena Hukum”, Vol.9, No.1 2016, 53-72, hlm.55.

${ }^{16}$ Maskur Hidayat, Pembaruan Hukum Terhadap Lembaga Praperadilan Melalui Putusan Pengadilan, "Jurnal Yuridika”, Vol.30, No.3, 2015, 505-524, hlm.509.

${ }^{17}$ Wanda Rara Farezha, Eddy Rifai, Gunawan Jatmiko, Analisis Putusan Hakim Praperadilan Dalam Perkara Tindak Pidana Korupsi (Studi Putusan Praperadilan Nomor 14/Pid.Pra/2016/PN.Tjk), “Jurnal Poenale”, Vol.5, No.3, 2017, 1-14, hlm.3.

${ }^{18}$ Mutiara Kania Panggabean, Implementasi Putusan Mahkamah Konstitusi Nomor 102/Puu-Xiii/2015 Mengenai Gugurnya Pemeriksaan Praperadilan (Studi Putusan Praperadilan Nomor 96/Pid.Prap/2017/PN.Jkt.Sel dan Putusan Praperadilan Nomor 133/Pid.Prap/2017/PN.Jkt.Sel), “Jurnal Mahupiki”, Vol.1, No.2, 2019, 1-36, hlm. 6
} 
tanggal 30 Juli 2015, Mantan Bupati Morotai, Rusli Sibua mengajukan permohonan pengujian atas beberapa pasal dalam Kitab Undang-Undang Hukum Acara Pidana (KUHAP) termasuk pasal mengenai gugurnya pemeriksaan praperadilan terhadap Undang-Undang Dasar Negara Republik Indonesia tahun 1945. Setelah diputus oleh Mahkamah Konstitusi dengan nomor 102/PUU-XIII/2015, maka perubahan baru dalam pelaksanaan praperadilan, yaitu praperadilan gugur ketika pokok perkara telah dilimpahkan dan telah dimulai sidang pertama terhadap pokok perkara atas nama Pemohon. Setelah keluarnya ketentuan mengenai waktu gugurnya praperadilan oleh Mahkamah Konstitusi, telah tercipta suatu penegasan atas ketentuan dalam Pasal 82 ayat (1) huruf (d) Kitab Undang-Undang Hukum Acara Pidana (KUHAP). ${ }^{19}$

Menindaklanjuti uraian penjelasan tersebut, penulis menemukan perkara praperadilan yang mengesampingkan frasa ataupun ketentuan dalam Pasal 82 ayat (1) huruf (d) Kitab UndangUndang Hukum Acara Pidana (KUHAP) jo Putusan Makhamah Konstitusi No.102/PUUXIII/2015 yaitu perkara praperadilan No. 3/Pid.Prap/2017/PN Kfm (dengan tersangka An. Stefanus Ari Mendez,dkk). Selain itu, untuk menemukan benang merah dari permasalahan penulis, maka penulis melakukan komparasi dengan perkara praperadilan No.2/Pid.Prap/2017/ PN Kfm (dengan tersangka An.Frederikus Lopes,dkk. Perkara ini memiliki selisih waktu 1 (satu) hari dengan perkara No.3/Pid.Prap/2017/PN Kfm, dalam hal ini perkara praperadilan melalui putusan praperadilan dinyatakan gugur, sedangkan perkara praperadilan dengan No.3/ Pid.Prap/2017/PN Kfm dinyatakan dikabulkan permohonan praperadilan tersebut oleh majelis hakim praperadilan. Berkaitan dengan hal itu, menurut penulis putusan praperadilan dengan No.3/Pid.Prap/2017/PN Kfm telah mengesampingkan norma atau frasa yang terdapat dalam pasal 82 ayat 1 huruf (d) Kitab Undang-Undang Hukum Acara Pidana (KUHAP) jo Putusan Makhamah Konstitusi No.102/PUU-XIII/2015.

Berdasarkan uraian latar belakang masalah tersebut diatas, tulisan ini bertujuan untuk menjawab pertanyaan penelitian yaitu mengapa permohonan praperadilan dalam perkara Praperadilan Nomor 3/Pid.Prap/2017/PN Kfm, pada Pengadilan Negeri Kefamenanu tidak dinyatakan gugur sesuai dengan Pasal 82 ayat (1) huruf (d) Kitab Undang-Undang Hukum Acara Pidana (KUHAP) jo. Putusan Mahkamah Konstitusi Nomor 102/PUU-XIII/2015?

\section{B. METODE PENELITIAN}

Penelitian ini merupakan peneliitian hukum normatif atau doktrinal yaitu penelitian terhadap data sekunder yang berupa bahan hukum primer, bahan hukum sekunder, dan bahan hukum tersier. Selain itu, penelitian ini menggunakan metode pendekatan Undang-Undang ${ }^{20}$, pendekatan kasus $^{21}$, dan pendekatan konsep ${ }^{22}$ yang akan dianalisis secara yuridis preskriptif. Analisnya melalui interpretasi dengan tetap memperhatikan konsistensi antara teori hukum, asas hukum dan kaidah hukum yang relevan dengan permasalahan dalam penelitian ini.

\section{PEMBAHASAN}

Hasil penelitian tentang kronologis proses penanganan perkara atas nama tersangka Frederikus Lopes, dkk serta tersangka atas nama Stefanus Ari Mendez, dkk dimulai dari Proses Penyidikan hingga proses pelimpahan perkara ke Pengadilan Tindak Pidana Korupsi pada Pengadilan Negeri Kupang secara terperinci diuraikan pada tabel 1.

\footnotetext{
${ }^{19}$ Ibid., hlm.7

${ }^{20}$ Peter Mahmud Marzuki. (2005). Penelitian Hukum, Jakarta:Kencana Prenadia Group, hlm.. 136.

${ }^{21}$ Ibid., hlm.158

${ }^{22}$ Ibid., hlm.177
} 
Tabel 1

Proses Penanganan Pokok Perkara dari Penyidikan hingga Pelimpahan ke PN

\begin{tabular}{|c|c|c|c|}
\hline No & Uraian Waktu Penanganan Perkara & 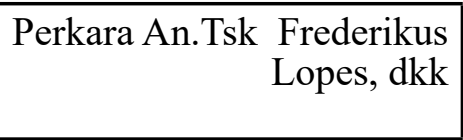 & $\begin{array}{r}\text { Perkara An.Tsk } \\
\text { Stefanus Ari } \\
\text { Mendez, dkk }\end{array}$ \\
\hline 1 & Surat Perintah Penyidikan & 27 Februari 2017 & 27 Februari 2017 \\
\hline 2 & $\begin{array}{r}\text { Surat Perintah Penahanan Tahap Peny- } \\
\text { idikan selama } 20 \text { hari (T-2) }\end{array}$ & 06 April 2017 & 06 April 2017 \\
\hline 3 & Berkas Perkara Lengkap (P-21) & 08 April 2017 & 08 April 2017 \\
\hline 4 & $\begin{array}{r}\text { Penyerahan Tersangka dan Barang Buk- } \\
\text { ti (Tahap II) }\end{array}$ & 17 April 2017 & 17 April 2017 \\
\hline 5 & $\begin{array}{r}\text { Surat Perintah Penunjukan JPU untuk } \\
\text { Penyelesaian Perkara Tindak Pidana } \\
\text { Korupsi (P-16A) }\end{array}$ & 18 April 2017 & 18 April 2017 \\
\hline 6 & $\begin{array}{r}\text { Surat Perintah Penahanan Tingkat } \\
\text { Penuntutan (T-7) }\end{array}$ & 18 April 2017 & 18 April 2017 \\
\hline 7 & Pelimpahan Perkara ke PN Tipikor & 19 April 2017 & 19 April 2017 \\
\hline 8 & Penetapan Hari Sidang Pokok Perkara & 19 April 2017 & 19 April 2017 \\
\hline 9 & Sidang Pokok Perkara & 25 April 2017 & April 2017 \\
\hline 10 & $\begin{array}{r}\text { Fakta agenda Sidang pada tgl } 25 \text { April } \\
2017 \text { berdasarkan Laporan Hasil } \\
\text { Persidangan Perkara (Pidsus-39) }\end{array}$ & $\begin{array}{r}\text { Telah dibacakan identitas } \\
\text { terdakwa namun Surat } \\
\text { Dakwaan belum diba- } \\
\text { cakan karena Penasehat } \\
\text { Hukum para terdakwa } \\
\text { berhalangan. }\end{array}$ & $\begin{array}{r}\text { Telah dibacakan } \\
\text { identitas } \\
\text { terdakwa } \\
\text { namun Surat } \\
\text { Dakwaan } \\
\text { belum diba- } \\
\text { cakan karena } \\
\text { Penasehat } \\
\text { Hukum para } \\
\text { terdakwa ber- } \\
\text { halangan. }\end{array}$ \\
\hline
\end{tabular}

Selanjutnya penulis akan menguraikan kronologis permohonan praperadilan terhadap kedua perkara sebagaimana diuraikan dalam tabel 2.

Tabel 2

Proses penanganan Perkara Permohonan Praperadilan

\begin{tabular}{|c|c|c|c|c|}
\hline No & $\begin{array}{r}\text { Para Pihak Pem- } \\
\text { ohon Prap- } \\
\text { eradilan }\end{array}$ & $\begin{array}{r}\text { Tgl Regis- } \\
\text { trasi } \\
\text { di PN } \\
\text { Kfm } \\
\end{array}$ & $\begin{array}{r}\text { Tgl Sidang } \\
\text { Pertama } \\
\text { Prap- } \\
\text { eradilan } \\
\end{array}$ & $\begin{array}{r}\text { Tgl \& Amar Putusan Permohonan Prap- } \\
\text { eradilan }\end{array}$ \\
\hline 1 & $\begin{array}{r}\text { Perkara No. 2/ } \\
\text { Pid.Prap/2017/ } \\
\text { PN Kfm An. } \\
\text { Tsk Frederikus } \\
\text { Lopes, dkk }\end{array}$ & $\begin{array}{r}10 \text { April } \\
2017\end{array}$ & 25 April 2017 & $\begin{array}{r}27 \text { April } 2017 \\
\text { Mengadili: } \\
\text { Menyatakan Permohonan Para Pemohon } \\
\text { gugur; } \\
\text { Membebankan biaya perkara kepada } \\
\text { para pemohon sejumlah nihil. }\end{array}$ \\
\hline
\end{tabular}




\begin{tabular}{|c|c|c|c|c|}
\hline 2 & $\begin{array}{r}\text { Perkara No. 3/Pid. } \\
\text { Prap/2017/PN } \\
\text { Kfm An. Tsk } \\
\text { Stefanus Ari } \\
\text { Mendez, SE., } \\
\text { dkk }\end{array}$ & $\begin{array}{r}10 \text { April } \\
2017\end{array}$ & $\begin{array}{r}25 \text { April } \\
2017\end{array}$ & $\begin{array}{r}28 \text { April } 2017 \\
\text { Mengadili: } \\
\text { Mengabulkan Permohonan Pemohon } \\
\text { Praperadilan untuk seluruhnya; } \\
\text { Menyatakan Surat Perintah Penyidikan- } \\
\text { Nomor } 16 / \text { P.3.12/Fd.1/02/2017 tgl } \\
27 \text { Februari } 2017 \text { dan Penetapan para } \\
\text { pemohon praperadilan sebagai ter- } \\
\text { sangka atas sangkaan melanggar....... } \\
\text { dst, adalah tidak sah dan tidak memi- } \\
\text { liki kekuatan hukum mengikat; } \\
\text { Menyatakan seluruh Perintah, Keputusan } \\
\text { dan Penetapan yang dikeluarkan lebih } \\
\text { lanjut oleh Termohon yang didasarkan } \\
\text { atas Surat Perintah Penyidikan Nomor } \\
16 / \text { P.3.12/Fd.1/02/2017 tgl 27 Feb- } \\
\text { ruari 2017 adalah tidak sah dan tidak } \\
\text { memiliki kekuatan hukum mengikat } \\
\text { termasuk surat penangkapan dan pen- } \\
\text { ahanan terhadap para pemohon adalah } \\
\text { tidak sah dan tidak memiliki kekuatan } \\
\text { hukum mengikat; } \\
\text { Membebankan biaya perkara kepada } \\
\text { Negara. }\end{array}$ \\
\hline
\end{tabular}

Sumber : Data Sekunder

Sesuai dengan data yang penulis himpun sebagaimana terdapat dalam putusan Praperadilan Nomor: 2/Pid.Prap/2017/PN.Kfm dan Nomor : 3/Pid.Prap/2017/PN.Kfm serta dokumendokumen lainnya, maka permasalahan ini berawal dari adanya dugaan Tindak Pidana Korupsi dalam pekerjaan fisik berupa Peningkatan Jalan Ruas Jl. Saenam Nunpo section 1 dengan nilai proyek sebesar Rp.1.921.147.000,- yang dilakukan oleh Tersangka Stefanus Ari Mendez, SE., dkk pada tahun 2013/2014 pada Badan Pengelola Perbatasan Kabupaten Timor Tengah Utara.

Pada tanggal 27 Februari 2017 Kepala Kejaksaan Negeri Timor Tengah Utara menerbitkan Surat Perintah Penyidikan Nomor : Print-16/P.3.12/Fd.1/02/2017 sebagai revisi terhadap Surat Perintah Penyidikan Nomor Print-10/P.3.12/01/2017 tanggal 11 Januari 2017 Jo. Surat Perintah Penyidikan Nomor : Print-08/P.3.12/Fd.1/04/2016 tanggal 04 April 2016 untuk melakukan Penyidikan terhadap perkara tersebut dengan memerintahkan Tim Penyidik yang berjumlah 8 (delapan) orang dan pada hari yang bersamaan juga dilakukan Penetapan Tersangka terhadap Stefanus Ari Mendez, SE.,dkk dengan diterbitkannya Surat Penetapan Tersangka Nomor 04/P.3.12/Fd.1/02/2017 tanggal 27 Februari 2017.

Selanjutnya pada tanggal 06 April 2017, Kepala Kejaksaan Timor Tengah Utara memerintahkan Tim Penyidik untuk melakukan Penahanan terhadap Tersangka di Rutan Kefamenanu selama 20 (dua Puluh) hari dengan menerbitkan Surat Perintah Penahanan Nomor :Print-120/P.3.12/Fd.1/04/2017 tanggal 06 April 2017.

Terhadap proses penyidikan tersebut, Stefanus Ari Mendez, SE selaku Direktur CV. Matahari Timur keadilan dengan didampingi oleh Penasehat Hukumnya Aleksander Frans, SH.,dkk menyatakan Praperadilan terhadap proses penyidikan dan penetapan tersangka yang dilakukan oleh Penyidik pada Kejaksaan Negeri Timor Tengah Utara, dengan nomor register 27/LGS.SRT.KHS/04/2017 tanggal 10 April 2017 yang selanjutnya disebut sebagai Pemohon 
Praperadilan, sedangkan Kepala Kejaksaan Negeri Timor Tengah Utara sebagai Termohon Praperadilan.

Sidang Praperadilan terhadap gugatan permohonan tersebut berlangsung pada tanggal 25 April 2017 bertempat di Pengadilan Negeri Kefamenanu. Sebelum proses sidang praperadilan tersebut berlangsung, Penyidik pada Kejaksaan Timor Tengah Utara sesuai dengan kewenangannya pada tanggal 17 April 2017 telah melimpahkan perkara pokok (perkara tindak pidana korupsi) tersebut ke Penuntut Umum pada Kejaksaan Negeri Timor Tengah Utara (Penyerahan Tersangka dan Barang Bukti), dan selanjutnya pada tanggal 19 April 2017 Perkara aquo oleh Penuntut Umum dilimpahkan ke Pengadilan Tipikor pada Pengadilan Negeri Kupang, sehingga Penahanan terhadap Terdakwa juga beralih dari Penuntut Umum ke Pengadilan Tipikor pada Pengadilan Negeri Kupang.

Ketua Pengadilan Tipikor pada Pengadilan Negeri Kupang yang menerima pelimpahan berkas perkara tersebut sesuai dengan kewenangan yang diberikan Undang-Undang pada hari itu juga menerbitkan Penetapan hari sidang Nomor : 25/Pen.Pid.Sus-TPK/2017/PN Kpg tanggal 25 April 2017, Jam 09.00 Wita bertempat di Pengadilan Tipikor Kupang serta memerintahkan Jaksa Penuntut Umum untuk menghadirkan Terdakwa Stefanus Ari Mendez, SE.,dkk berikut saksi-saksinya dengan membawa barang buktinya.

Dengan demikian telah terjadi sidang praperadilan terhadap Tersangka Stefanus Ari Mendez, SE.,dkk pada tanggal 25 April 2017 bertempat pada Pengadilan Negeri Kefamenanu, dan hari yang sama juga dilaksanakan sidang terhadap Terdakwa Stefanus Ari Mendez, SE.,dkk pada Pengadilan Negeri Tipikor Kupang

\section{Analisis Kasus dan korelasinya Dengan Norma Hukum Positif}

Praperadilan terdapat dalam Pasal 1 butir 10 Kitab Undang-Undang Hukum Acara Pidana (KUHAP) yang berbunyi "Praperadilan adalah wewenang pengadilan negeri untuk memeriksa dan memutus menurut cara yang diatur dalam undang-undang ini, tentang:

a. Sah atau tidaknya suatu penangkapan dan/atau penahanan atas permintaan atau keluarganya atau pihak lain atas kuasa tersangka;

b. Sah atau tidaknya penghentian penyidikan atau penghentian penuntutan atas permintaan demi tegaknya hukum dan keadilan;

c. Permintaan ganti kerugian atau rehabilitasi oleh tersangka atau keluarganya atau pihak lain atas kuasanya yang perkaranya tidak diajukan ke pengadilan”.

Dengan demikian, yang menjadi ruang lingkup praperadilan telah dibatasi kewenangannya sebagaimana telah diterangkan dalam Pasal 1 butir 10 Kitab Undang-Undang Hukum Acara Pidana (KUHAP) dan dapat dijabarkan sebagai berikut: ${ }^{23}$

a. Sah atau tidaknya penangkapan;

b. Sah atau tidaknya penahanan;

c. Sah atau tidaknya penghentian penyidikan;

d. Sah atau tidaknya penghentian penuntutan;

e. Ganti kerugian dan atau rehabilitasi bagi seorang yang perkaranya dihentikan pada tingkat penyidikan;

f. Ganti kerugian dan atau rehabilitasi bagi seorang yang perkaranya dihentikan pada tingkat penuntutan.

${ }^{23}$ Soeparmono R. (2003). Praperadilan dan Penggabungan Perkara Gugatan Ganti Kerugian dalam Kuhap. Bandung: CV. Mandar Maju, hlm.22. 
Lebih lanjut dalam putusan Mahkamah Konstitusi Nomor 21/PUU-XII/2014 telah memperluas ruang lingkup praperadilan dalam Pasal 77 huruf a Undang-Undang Nomor 8 Tahun 1981 tentang Kitab Undang-Undang Hukum Acara Pidana (KUHAP) antara lain :

a. sah atau tidaknya penetapan tersangka;

b. Sah atau tidaknya penggeledahan;

c. Sah atau tidaknya penyitaan;

d. Sah atau tidaknya pemeriksaan surat.

Persoalan praperadilan telah menjadi wewenang Pengadilan Negeri seperti kewenangan lainnya dalam memeriksa dan memutus perkara pidana dan perdata. Persoalan praperadilan telah menjadi bagian dari tugas-tugas dan wewenang Pengadilan Negeri yang tidak boleh ditangani oleh Pengadilan dalam lingkungan peradilan lain. Namun perlu diperhatikan bahwa proses acara praperadilan bukanlah sebagian dari tugas memeriksa dan memutuskan (mengadili) perkara tindak pidananya itu sendiri, sehingga putusan praperadilan bukanlah merupakan tugas dan fungsi untuk menangani suatu tindak pidana (pokok perkara) yang berupa memeriksa dan memutus perkara tindak pidana yang berdiri sendiri sebagai putusan akhir. ${ }^{24} \mathrm{Kitab}$ UndangUndang Hukum Acara Pidana telah mengatur kewenangan Praperadilan secara khusus dalam Pasal 77 s/d Pasal 83

Beranjak dari data-data sebagaimana telah diuraikan sebelumnya maka peneliti menklasifikasi beberapa norma sehubungan dengan pokok pembahasan ini yang tergolong dalam hukum positif. Hukum positif itu sendiri merupakan hukum yang sedang berlaku saat ini. Hukum Positif dimaksud terdiri dari :

1. Undang-Undang Dasar Tahun 1945

2. Kitab Undang-Undang Hukum Acara Pidana (KUHAP)

3. Undang-Undang Nomor 8 Tahun 2011 Tentang Perubahan atas Undang-Undang Nomor 24 Tahun 2003 Tentang Mahkamah Konstitusi

4. Undang-UndangNomor 12 Tahun2011 TentangPembentukanPeraturanPerundang-undangan

5. Undang-Undang Nomor 48 Tahun 2009 Tentang Kekuasaan Kehakiman

6. Undang-Undang Nomor 16 Tahun 2004 Tentang Kejaksaan

Sesuai dengan Pasal 7 Undang-Undang Nomor 12 Tahun 2011 tentang Pembentukan Peraturan Perundang-undangan maka Undang-Undang Dasar Tahun 1945 menempati posisi tertinggi/ Grundnorm kemudian diikuti oleh lima undang-undang lainnya yang memiliki kedudukan/posisi yang sama di urutan kedua, sebagaimana dikemukakan oleh Hans Kelsen mengenai Stufenbautheori bahwa pada dasarnya kaidah-kaidah hukum itu berbentuk piramida/ tersusun secara bertingkat-tingkat mulai dari yang paling rendah sampai yang paling tinggi, oleh karenanya kaidah hukum yang paling rendah tidak boleh bertentangan dengan kaidah hukum yang lebih tinggi. ${ }^{25}$

Pasal 82 ayat (1) huruf d Kitab Undang-Undang Hukum Acara Pidana yang menjadi pokok permasalahan ini berada pada posisi dibawah Undang-Undang Dasar Tahun 1945, oleh karena itu tidak boleh bertentangan dengan Undang-Undang Dasar 1945. Pada tahun 2003 telah muncul Undang-Undang Mahkamah Konstitusi yang mempunyai tugas untuk mengawal konstitusi (to guard), dalam perjalanannya Pasal 82 ayat (1) huruf (d) ini menimbulkan multitafsir di kalangan para penegak hukum baik itu Polisi, Jaksa, Hakim, maupun Penasehat Hukum khususnya pada frasa "sudah mulai diperiksa"

Pendapat penulis tentang teori piramida Hans Kelsen sudah sangat sesuai dengan peruntukkannya bahwa susunan sistem perundang-undangan seyiogianya tidak boleh

\footnotetext{
${ }^{24}$ Ibid., hlm.12

${ }^{25}$ Maria Farida Indrati Suprapto. (1998). Ilmu Perundang-Undangan. Yogyakarta: Kanisius, hlm. 6
} 
bertentangan satu dengan lainnya baik secara vertikal maupun horizontal agar terciptanya suatu kepastian hukum yang harmonis.

Setelah penulis mengelompokan norma-norma hukum positif sesuai dengan urutannya selanjutnya yang menjadi pertanyaan agar dapat ditemukan konklusi adalah apakah perkara permohonan praperadilan nomor 2/Pid.Prap/2017/PN Kfm dan 3/Pid.Prap/2017/PN Kfm telah dilimpahkan dan telah dimulai sidang pertama sehingga hakim tunggal yang memimpin persidangan Permohonan Praperadilan tersbut harus menyatakan putusan tersebut gugur?

Untuk menjawab pertanyaan diatas maka penulis menelusuri pandangan para ahli serta aturan-aturan terkait gugurnya praperadilan, antara lain :

1. Menurut Yahya Harahap dalam bukunya Pembahasan dan Permasalahan dan penerapan Kitab Undang-Undang Hukum Acara Pidana memberi pandangan bahwa gugurnya pemeriksaan praperadilan sebagaimana diatur dalam Pasal 82 Ayat (1) huruf(d) Kitab Undang-Undang Hukum Acara Pidana terjadi: ${ }^{26}$

1) apabila perkaranya telah diperiksa oleh Pengadilan Negeri, dan

2) padasaatperkaranyadiperiksa PengadilanNegeri,PemeriksaanPraperadilanbelumselesai.

Hal inilah yang menyebabkan gugurnya pemeriksaan permintaan Praperadilan. Apabila perkara (pokok) telah diperiksa Pengadilan Negeri, sedang Praperadilan belum menjatuhkan putusan, dengan sendirinya permintaan Praperadilan gugur. Hal ini dmaksudkan untuk menghindari terjadinya penjatuhan putusan yang berbeda. Selanjutnya Harahap menyatakan bahwa lebih tepat Pemeriksaan Praperadilan dihentikan dengan jalan menggugurkan permintaan, dan sekaligus semua hal yang berkenaan dengan perkara itu ditarik ke dalam kewenangan Pengadilan Negeri untuk menilai dan memutusnya.

Fakta yang terungkap di lapangan adalah putusan terhadap permohonan Praperadilan Nomor 3/Pid.Prap/2017/PN.Kfm tanggal 28 April 2017 tidak gugur sekalipun perkara pokoknya resmi telah digelar pada tanggal 25 April 2017, ${ }^{27}$ sehingga berbeda dengan Hakim yang menggelar perkara pokok tersebut. Perbedaan tersebut terletak pada Penetapan kedua hakim yakni pada tanggal 28 april 2017 Hakim tunggal Decky Nitbani yang memimpin sidang permohonan Praperadilan di Pengadilan Negeri Kefamenanu menetapkan agar para Tersangka dibebaskan dari tahanan, sedangkan pada tanggal 19 April 2017, Majelis hakim Tindak Pidana Korupsi pada PN Kupang telah menerima pelimpahan perkara tersebut dan selanjutnya mengeluarkan perintah agar terhadap para terdakwa dilakukan Penahanan di Rutan Kupang. Hal ini menimbulkan perbedaan putusan sebagaimana telah disampaikan oleh Yahya Harahap di atas, sehingga berakibat tidak adanya kepastian hukum terhadap para tersangka/terdakwa.

Penulis sangat sependapat dengan apa yang disampaikan Ahli Hukum Yahya Harahap dimanagugurnya praperadilan terjadiketika suatu perkara pokok telah diperiksa di Pengadilan Negeri, dan pada saat diperiksa, permohonan praperadilannya belum selesai. Demikian juga dengan pertimbangan hakim Yefri Bimusu yang menggugurkan permohonan praperadilan 02/Pid.Prap/2017/PN.Kfm dengan alasan perkara pokoknya telah dilimpahkan ke Pengadilan Tindak Pidana korupsi pada Pengadilan Negeri Kupang sehingga hal ini sesuai dengan hakikat Pasal 82 Ayat (1) huruf (d) KUHAP Jo. Putusan Mahkamah Konstitusi Nomor 102/ PUU-XIII/2015. ${ }^{28}$

2. Lilik Mulyadi mendefenisikan dimulainya Pemeriksaan di Persidangan yakni pada tahap pemeriksaan identitas terdakwa, pembacaan dakwaan oleh Jaksa Penuntut Umum, kemudian diberikan kesempatan kepada Terdakwa/ Penasehat Hukum untuk mengajukan keberatan/

\footnotetext{
${ }^{26}$ Yahya Harahap.( 2003). Pembahasan, Permasalahan dan Penerapan KUHAP. Jakarta:Sinar Grafika, hlm. 20

${ }^{27}$ Lihat Putusan Nomor 3/Pid.Prap/2017/PN.Kfm

${ }^{28}$ Lihat Putusan Praperadilan nomor : 2/Pid.Prap/2017/PN.Kfm, hlm. 27.
} 
eksepsi, selanjutnya acara pembuktian, penuntutan, pembelaan, replik dan duplik, serta pemeriksaan selesai dan dilanjutkan dengan musyawarah dalam mengambil keputusan oleh majelis hakim sebagaimana telah diatur dalam Pasal $145 \mathrm{~s} / \mathrm{d} 232$ Kuhap).${ }^{29}$ Pendapat Mulyadi ini berkaitan dengan frasa "perkara sudah mulai diperiksa" yang tercantum dalam Pasal 82 Ayat (1) huruf (d) Kuhap yakni pemeriksaan terhadap perkara pokok dimulai pada saat pembacaan Identitas terdakwa, dan bukan pada saat dibacakannya Surat dakwaan atau Surat tuntutan, dan seterusnya.

Fakta persidangan sesuai dengan uraian tentang kronologis sebagaimana pada tabel 2 telah memberi gambaran jelas bahwa baik perkara nomor : 2/Pid.Prap/2017/PN Kfm dan nomor : 3/Pid.Prap/2017/PN Kfm telah dilimpahkan ke Pengadilan Tindak Pidana Korupsi pada Pengadilan Negeri Kupang pada tanggal yang sama tepatnya tanggal 19 April 2017, berdasarkan Surat Pelimpahan Perkara Acara Pemeriksaan Biasa (P-31) Nomor : B-40/P.3.12/ Ft.1/04/2017 Tanggal 18 April 2017. Selanjutnya Majelis Hakim menetapkan Penahanan dan selanjutnya menetapkan hari sidang pada tanggal 25 April 2017 dan pada hari Senin tanggal 25 April 2017, berdasarkan Laporan Hasil Persidangan (Pidsus-39), sidang digelar serta Majelishakimmembacakanidentitas terdakwayang tertera dalam surat dakwaan dan terdakwa membenarkannya. Sedangkan mengenai pembacaan surat dakwaan ditunda persidangannya hingga tanggal 2 Mei 2017, karena Penasehat Hukum yang bersangkutan tidak hadir dalam sidang perkara pokok sehubungan dengan berlangsungnya sidang praperadilan di Kefamenanu pada hari dan tanggal yang sama.

Lebih lanjut, hakim Mahkamah Konstitusi Arif Hidayat, dkk yang beranggotakan 9 (sembilan)orangsepertidikutipdalamrisalahPutusanMahkamahKonstitusiNomor 102/PUUXIII/2015 tanggal 09 November 2016 telah mencabut frasa "perkara mulai diperiksa" karena nyata-nyata telah bertentangan dengan Undang-Undang Dasar Tahun 1945. Demi kepastian hukum dan keadilan Mahkamah mencabut frasa tersebut menjadi "perkara praperadilan gugur pada saat pokok perkara telah dilimpahkan dan telah dimulai sidang pertama terhadap perkara pokok atas nama terdakwa/ pemohon praperadilan".

Sedangkan mengenai sidang pertama, maka pasal 155 KUHAP telahmenjelaskan tentang susunan dalam proses persidangan sebagai berikut:

Ayat (1):

Pada permulaan sidang, hakim ketua sidang menanyakan kepada terdakwa tentang nama lengkap, tempat lahir, umur atau tanggal lahir, jenis kelamin, kebangsaan, tempat tinggal, agama dan pekerjaannya serta mengingatkan terdakwa supaya memperhatikan segala sesuatu yang didengar dan dilihatnya di sidang.

Ayat (2):

a. Sesudah itu hakim ketua sidang minta kepada penuntut umum untuk membacakan surat dakwaan.

b. Selanjutnya hakim ketua sidang menanyakan kepada terdakwa apakah ia sudah benarbenar mengerti, apabila ternyata ia tidak mengerti penuntut umum atas permintaan hakim ketua sidang, wajib memberi penjelasan yang diperlukan.

Susunan proses persidangan ini terus berlanjut sampai dengan adanya putusan yang termuat dalam pasal 196 KUHAP.

Frasa "pada permulaan sidang" yang terdapat pada Pasal 155 ayat (1) KUHAP memberi makna bahwa sidang pertama telah dimulai. Kata "Permulaan" dalam Kamus BesarBahasa Indonesia berarti: awal; yangpertama sekali; yangpalingdahulu. sedangkan kata "mulai" dalam Kamus besar Bahasa Indonesia diartikan sebagai : mengawali berbuat (bertindak, melakukan, dsb) sehingga walaupun kedua kata tersebut berbeda, namun

\footnotetext{
${ }^{29}$ Lilik Mulyadi. (2007). Putusan Hakim dalam Hukum Acara Pidana. Bandung: PT. Citra Aditya Bakti, hlm. .3.
} 
memiliki makna yang sama pada kata "awal". Dengan demikian maka makna dalam frasa "pada permulaan sidang" yang terdapat pada Pasal 155 Ayat (1) KUHAP dalam penerapannya dapat menjawab kapan waktunya sidang pertama dimulai, dimana Sidang pertama dimulai pada saat pembacaan indentitas terdakwa, maka dengan dibacakannya indentitas terdakwa, sidang perdana/pertama telah dinyatakan dimulai.

Terkait kapan selesainya sidang pertama itu sendiri tidak diatur dalam KUHAP atau dengan kata lain kapan sidang kedua dimulai juga secara tegas tidak diatur dalam KUHAP, akan tetapi dalam praktik persidangan, Ketua Majelis Hakim selalu membacakan agenda sidang berikutnya dengan menyebutkan hari dan tanggal sidang, sedangkan yang diatur dalam KUHAP adalah uraian proses persidangan dimulai dari pembacaan identitas terdakwa sampai dengan sidang pembacaan putusan.

Penelitian ini, penulis menemukan terdapat perbedaan yang sangat signifikan antara Putusan Permohonan Praperadilan Nomor 2/Pid.Prap/2017/PN Kfm dan Nomor 3/Pid. Prap/2017/PN Kfm yang terletak pada penafsiran masing-masing hakim praperadilan terhadapfrasa"SidangPertama"yangterdapatdalamPutusanMahkamahKonstitusiNomor 102/PUU-XIII/2015yangmempertegas frasa "suatuperkarasudahmulaidiperiksa" dalam Pasal 82 ayat (1) huruf d KUHAP. Hakim Yefri yang memeriksa perkara Nomor 2/Pid. Prap/2017/PN Kfm menafsirkan bahwa sidang pertama yang dimaksud dalam Putusan Mahkamah Konstitusi diatas adalah sidang perdana pada tanggal 25 April 2017sesuai dengan Penetapan Hakim Ketua Majelis Nomor : Pen.Pid.Sus-TPK/2017/PN.Kpg (uraian pada tabel2) dengan agenda persidangan pembacaan identitas terdakwa sebagaimana telah dijelaskan dalam Pasal 155 ayat (1) KUHAP. Sedangkan penafsiran berbeda diucapkan oleh hakim Nitbani pada tanggal 28 April terhadap perkara permohonan praperadilan nomor 3/Pid.Prap/2017/PN Kfm yang menyatakan bahwa sidang pertama belum dimulai karena baru dibacakan identitas namun belum dibacakan surat dakwaan. Untuk menguji apakah dengan tidak dinyatakan gugurnya permohonan praperadilan ini sudah sesuai dengan norma hukum yang berlaku atau sebaliknya bertentangan dengan aturan yang telah ada, maka penulis menelusuri apa yang menjadi landasan Mahkamah Konstitusi mempertegas frasa "suatu perkara sudah mulai diperiksa" yang diatur dalam Pasal 82 ayat (1) huruf d KUHAP dan Peneliti menemukan alasan dimaksud yaitu karena terjadi multitafsir di antara para penegak hukumantara lain:

1) Ada Pandangan yang menyatakan bahwa "suatu perkara sudah mulai diperiksa" ketika pokok perkara telah dilimpahkan ke Pengadilan Negeri”;

2) Adajugapandanganyangmenyatakanbahwa "suatuperkarasudah mulaidiperiksa" ketika sidang pertama dimulai";

3) Pandangan yang lain menyatakan bahwa "suatu perkara sudah mulai diperiksa" ketika Surat dakwaan dibacakan.

Dari ketiga alasan tersebut diatas Mahkamah menyatakan Pendapat dengan mengakomodir pendapat pada point 1 dan 2 yang berbunyi :

Perkara Praperadilan gugur ketika perkara pokok telah dilimpahkan dan telah dimulai sidang pertama, kecuali pandangan sebagaimana pada point 3 yang menyatakan Perkara Praperadilan gugur ketika surat dakwaan dibacakan. Maka dengan demikian telah jelas bahwa apa yang dinyatakan oleh hakim Nitbani tentang "sidang pertama dimulai ketika sudah dibacakan surat dakwaan bertentangan dengan putusan Mahkamah Konstitusi Nomor 102/PUU-XIII/2015 Jo. Pasal 155 ayat (1) KUHAP”.

Dari beberapa pandangan tersebut serta mencermati fakta persidangan, Peneliti sependapatdenganapayang disampaikanoleh paraahli, bahwasannyaketikapokokperkara telah dilimpahkan dan dimulai sidang pertama, maka sidang permohonan praperadilan 
Nomor: 3/Pid.Prap/2017/PN.Kfm sepatutnya dinyatakan gugur dengan alasan sebagai berikut :

1. bahwa Pasal 82 Ayat (1) huruf (d) yang berbunyi : "dalam hal suatu perkara sudahmulaidiperiksaolehpengadilan negeri,sedangkan pemeriksaanmengenai permintaan belum selesai, maka permintaan tersebut gugur".

2. bahwa dalam perjalanannya pasal ini menimbulkan multitafsir pada frasa "perkara sudah mulai diperiksa", namun sesuai dengan kewenangan Mahkamah Konstitusi maka frasa tersebut telah dicabut serta dipertegas menjadi "Praperadilan gugur ketika perkara pokok telah dilimpahkan dan telah dimulai sidang pertama".

3. bahwa terdapat perbedaan putusan antara hakim Yefri Bimusu yang menggugurkan Permintaan Praperadilan Pemohon dan hakim Nitbaniyang mengabulkan Permintaan Praperadilan Pemohon disebabkan karena berbeda penafsiran pada frasa "dimulai sidangpertama”sebagaimanadiaturdalamPutusanMKNomor:102/PUU-XIII/2015 Jo.Pasal 155Ayat(1)KUHAP, dan terhadap perbedaan tersebut, dengan berpedoman pada Pasal 155 KUHAP, dan berdasarkan landasan awal Mahkamah Konstitusi mencabut frasa tersebut, maka penulis sependapat dengan Hakim Yefri Bimusu agar permohonan praperadilan tersebut gugur.

4. bahwa Mengenai persoalan hadir tidaknya Penasehat Hukum pada sidang perkara pokok, maka hal tersebut tidaklah menjadi alasan yang mutlak bagi hakim untuk menunda pesidangan, kecuali hakim memiliki pertimbangan yang mendasar lainnya untuk menunda pembacaan Surat Dakwaan pada persidangan berikut karena Pasal 198 Kuhap telah memberi makna yang jelas dengan berbunyi demikian :

Ayat (1) : Dalam hal seorang hakim atau penuntut umum berhalangan, maka ketua pengadilan atau pejabat kejaksaan yang berwenang wajib segera menunjuk pengganti pejabat yang berhalangan tersebut.

Ayat (2) : Dalam hal penasehat hukum berhalangan, ia menunjuk penggantinya dan apabila penggantinya ternyata tidak ada atau juga berhalangan, maka sidang berjalan terus.

\section{Analisis terhadap asas-asas hukum}

Untuk memperjelas penelitian dalam bentuk Normatif ini, maka Peneliti juga melakukan penjelajahan terhadap pendapat para ahli tentang asas-asas hukum. Asas-asas hukum dimaksud dalam kaitannya dengan penelitian ini hanya mencakup asas hukum acara pidana. Asas Hukum Acara Pidana menurut Mulyadi dapat diuraikan sebagai berikut: ${ }^{30}$

\section{1) Asas Equality before The Law}

Asas ini menekankan bahwa harus adanya perlakuan yang sama, wajar dan seimbang di depan hukum. Hemat Penulis dalam mencermati proses penanganan perkara praperadilan dalam kasus ini, maka Penerapan dari asas ini dalam proses penanganan perkara korupsi yang dilakukan Penyidik maupun Penuntut Umum terhadap kedua tersangka dalam kasus ini sudah sesuai dengan aturan yang berlaku. Hal ini dapat dilihat dari waktu penanganan perkara dari penyidikan hingga penuntutan dilakukan secara serentak/bersama-sama, sedangkan perbedaannya karena kedua perkara tersebut di Spiltzing oleh Penyidik maupun Penuntut Umum menjadi dua berkas.

Selain dari waktu penanganan perkara, hak-hak dari para tersangka seperti hak untuk mendapat pembelaan dan hak untuk mengajukan permohonan praperadilan tidak dibatasi oleh Penyidik maupun Penuntut Umum. Asas ini bertolak belakang dengan proses penanganan

\footnotetext{
${ }^{30}$ Ibid., hlm. 7 .
} 
perkara ini ketika perkara permohonan praperadilan diputus oleh kedua hakim yang berbeda, dimana perkara permohonan praperadilan nomor 02/Pid.Prap/2017/PN Kfm diputus gugur, sedangkan permohonan praperadilan nomor 03/Pid.Prap/2017/PN Kfm tidak dinyatakan gugur sesuai dengan amanat Undang-Undang Nomor 8 Tahun 1981 Tentang KUHAP.

2) Penangkapan, Penahanan, Penggeledahan, dan Penyitaan hanya dilakukan berdasarkan Perintah Tertulis oleh Pejabat yang diberi wewenang oleh Undang-Undang dan hanya dalam hal dan cara yang diatur oleh Undang-Undang.

Sesuai Konteks ini, maka tidak diperkenankan suatu tindakan berupa Penangkapan, Penahanan, Penggeledahan serta penyitaan dilakukan secara lisan, namun sebaliknya harus dilakukan secara yuridis formal dengan bentuk tertulis. Jika dilakukan dengan perintah lisan maka konsekuensinya adalah batal demi hukum. Konkritnya pelaksanaan proses penanganan perkara aquo dari penyidikan hingga Putusan dilaksanakan dengan Surat Perintah secara tertulis, dengan demikian asas ini tidak dilanggar oleh para penegak hukum karena sesuai dengan datadata yang Peneliti gambarkan dalam tabel nomor 2 dan 3, maka semua dilaksanakan dengan Surat Perintah Tertulis serta dibuatkan Berita Acara.

Berdasarkan uraian diatas, penulis senada dengan Pendapat Lilik Mulyadi tentang Asas dimaksud karena dari hasil Penelitian, Penulis tidak menemukan adanya perbedaan perlakuan terhadap proses penanganan perkara baik perkara nomor 2/Pid.Prap/2017/PN.Kfm maupun perkara nomor 3/Pid.Prap./2017/PN.Kfm.

3) Asas peradilan cepat, sederhana, dan biaya ringan serta bebas, jujur serta tidak memihak.

Pemahaman terhadap asas ini menurut Andi Hamzah dalam bukunya Asas-Asas Hukum Pidana adalah agar proses Penyidikan dan Penuntutan yang dilakukan oleh Penyidik, Penuntut Umum dan Hakim tidak sampai berlarut-larut, dapat memberikan kepastian hukum serta proses administrasi biaya perkara yang ringan dan tidak terlalu membebani tersangka/terdakwa, maka berdasarkan Surat Edaran Mahkamah Agung Republik Indonesia Nomor 6 Tahun 1992 tanggal 21 oktober 1992 menetapkan batas waktu yang ditentukan dalam penanganan perkara baik perdata maupun pidana adalah enam bulan. Selain ketentuan Mahkamah Agung Republik Indonesia, juga dalam Pasal 110 Ayat (1) KUHAP telah ditentukan bahwa dalam hal penyidik telah selesai melakukan penyidikan, penyidik wajib segera menyerahkan berkas perkara itu kepada penuntut umum.

Jangka Waktu Penuntut Umum dalam melimpahkan berkas perkara ke Pengadilan secara khusus memang tidak diatur dalam KUHAP, namun terdapat ketentuan dalam Pasal 139 KUHAP yang menyatakan bahwa "setelah penuntut umum menerima atau menerima kembali hasil penyidikan yang lengkap dari penyidik, ia segera menentukan apakah berkas perkara itu sudah memenuhi syarat untuk dapat atau tidak dilimpahkan ke pengadilan". Demikian juga dengan Pasal 140 Ayat (1) KUHAP yang menegaskan "dalam hal penuntut umum berpendapat bahwa dari hasil penyidikan dapat dilakukan penuntutan, ia dalam waktu secepatnya membuat surat dakwaan".

Frasa "segera" dalam pasal 139 KUHAP dan frasa "dalam waktu secepatnya" yang terdapat dalam pasal 140 Ayat (1) KUHAP menurut hemat Penulis memberi makna bahwa dalam waktu yang tidak sampai berlarut-larut,Penuntut Umum sudah harus melimpahkan berkas perkara tersebut ke Pengadilan. Hal ini dilakukan dengan tujuan dasar ialah menjunjung tinggi asas peradilan cepat sebagaimana telah dikemukakan.

Asas ini tidak hanya berlaku di kalangan penyidik dan Penuntut Umum tetapi di Pengadilan juga menerapkan asas yang sama sebagaimana ditentukan dalam Pasal 2 ayat (4) Undang- 
Undang Nomor 48 Tahun 2009 Tentang Kekuasaan kehakiman bahwa : Peradilan dilakukan dengan sederhana, cepat dan biaya ringan.

Selain asas Peradilan Cepat, juga terdapat ketentuan lain dalam Pasal 10 UU Nomor 48 Tahun 2009 Tentang Kekuasaan Kehakiman yang berbunyi : "Pengadilan dilarang menolak untuk memeriksa, mengadili dan memutus suatu perkara yang diajukan dengan dalih hukum tidak ada atau kurang jelas, melainkan wajib untuk memeriksa dan mengadilinya".

\section{4) Asas Praduga Tidak Bersalah atau Presumption of Innocence}

Asas "Praduga tidak bersalah" eksistensinya terdapat dalam Pasal 8 Undang-Undang No. 14 Tahun 1970 Jo. Undang-Undang Nomor 35 Tahun 1999 Jo. Undang-Undang No. 4 Tahun 2004 dan Penjelasan Umum angka (3) huruf (c) KUHAP yang menentukan bahwa :

"Setiap orang yang disangka, ditangkap, ditahan, dituntut, dan atau dihadapkan dimuka sidang pengadilan wajib dianggap tidak bersalah sampai adanya putusan pengadilan yang menyatakan kesalahannya dan memperoleh kekuatan hukum tetap".

Penegasan dari asas ini tampak jelas bahwa seorang tersangka/terdakwa yang belum mendapat putusan yang berkekuatan hukum tetap haruslah dianggap tidak bersalah, sehingga selama dalam proses peradilan tersangka/terdakwa tetap mendapatkan hak-haknya sebagaimana diatur oleh Undang-Undang, yaitu hak untuk segera mendapatkan pemeriksaan dalam tahap penyidikan, hak untuk mendapatkan pemeriksaan di pengadilan serta mendapatkan putusan yang seadil-adilnya, hak mendapatkan juru bahasa, hak untuk memperoleh bantuan hukum, hak untuk mendapatkan upaya hukum, dan sebagainya.

Praktek terhadap putusan praperadilan sebagaimana dalam pokok persoalan diatas, asas ini masih bersifat kasuistis, dimana pihak tersangka/terdakwa berpendapat bahwa haknya untuk menempuh jalur praperadilan diabaikan karena penyidik maupun Penuntut Umum bergegas untuk melimpahkan perkara pokoknya ke pengadilan yang berwenang dalam hal ini Pengadilan Tindak Pidana Korupsi pada Pengadilan Negeri Kupang. Sedangkan berbeda dengan dalil dari pada Penyidik maupun Penuntut Umum yang menyatakan bahwa tindakan yang dilakukan oleh Penyidik maupun Penuntut Umum telah sesuai dengan aturan yang berlaku yakni proses penyidikan perkara aquo sudah dimulai sejak bulan Februari 2017 dan baru dilimpahkan ke Pengadilan Negeri pada bulan April 2017 bertepatan dengan proses permohonan praperadilan tersangka. Terkait lambat atau cepatnya jangka waktu tersebut merupakan waktu yang relatif dalam proses penyidikan maupun penuntutan.

Dari perbedaan pendapat di atas, penulis berpendapat bahwa terdapat kurangnya koordinasi antara para penegak hukum khususnya Penuntut Umum dengan hakim Praperadilan atau antara Pengadilan Negeri yang memeriksa perkara pokok dengan Hakim Praperadilan dalam hal pemberitahuan pelimpahan perkara pokok oleh Penuntut Umum ke pengadilan negeri, sehingga proses penanganan perkara praperadilan tetap dilanjutkan bahkan mendapat putusan yang bertentangan dengan Pasal 82 Ayat (1) huruf (d) Kuhap. Oleh karena itu dalam tulisan ini, penulis sangat mengharapkan adanya suatu norma yang secara tegas mengatur tentang hal tersebut dengan ketentuan bahwa :

a. Harus adanya Koordinasi secara tertulis yang dilakukan oleh Penuntut Umum dan/atau Pengadilan Negeri yang berwenang memeriksa perkara pokok dengan Pengadilan Negeri/

Hakim Praperadilan yang memeriksa permohonan praperadilan perkara tersebut.

b. DalamhalPengadilanNegeri/HakimPraperadilantelahmenerimaPemberitahuanPelimpahan perkaraolehPenuntutumum kepengadilanNegeri, MakaHakimPraperadilanyangmemeriksa perkara aquo wajib menetapkan perkara tersebut gugur.

Dengan adanya kedua norma di atas, maka tentunya tidak akan terjadi saling menuduh antara Pihak terdakwa dan/atau Penasehat hukum dengan Pihak Penuntut Umum dan hal ini 
akan melengkapi hakikat yang terdapat dalam Pasal 82 Ayat (1) huruf (d) Kuhap Jo Putusan Mahkamah Konstitusi Nomor : 102/PUU-XIII/2015.

\section{Analisis terhadap Sistematika Undang-Undang}

Pedoman utama dalam melakukan penelitian terhadap sistematika Undang-Undang adalah Undang-Undang Republik Indonesia Nomor 12 Tahun 2011 Tentang Pembentukan Peraturan Perundang-undangan, khususnya dalam pasal 7 yang memuat Jenis dan Hirearki Peraturan Perundang-undangan yang terdiri atas:

1) Undang-Undang Dasar Negara Republik Indonesia;

2) Ketetapan Majelis Permusyawaratan Rakyat;

3) Undang-Undang/Peraturan Pemerintah Pengganti Undang-Undang;

4) Peraturan Pemerintah;

5) Peraturan Presiden;

6) Peraturan Daerah Provinsi; dan

7) Peraturan Daerah Kabupaten/Kota

Sesuai dengan beberapa Peraturan yang telah Peneliti Inventarisasi, maka peraturan tersebut berdasarkan teori Hans Kelsen (Stufenbautheori) dari yang terendah sampai tertinggi dapat terurai sebagai berikut:

1) Kaidah hukum individual atau kaidah hukum konkrit dari badan-badan hukum pelaksana/ penegak hukum, terutama pengadilan

2) Kaidah hukum umum atau kaidah hukum abstrak di dalam Undang-Undang

3) Kaidah hukum konstitusi

Dari uraian diatas, maka penelitian secara vertikal penulis menemukan putusan hakim praperadilan yaitu Putusan Nomor 3/Pid.Prap/2017/PN.Kfm yang berada pada posisi terendah bertentangan dengan Undang-Undang No.8 Tahun 1981 khususnya dalam pasal 82 ayat (1) huruf d KUHAP yang dan berada pada posisi satu tingkat lebih tinggi, sedangkan secara horizontal maka putusan praperadilan tersebut bertentangan dengan putusan hakim Mahkamah Konstitusi nomor 102/PUU/VIII/2015.

\section{Hasil Analisis terhadap Fakta hukum secara Abstrak dan Konkrit}

Melakukan Penelitian ini, maka yang penulis temukan hukum in abstraco ialah Pasal 82 ayat (1) huruf d KUHAP sebagai premisa major yang menentukan bahwa apabila suatu perkara pokok telah dilimpahkan ke Pengadilan, sedangkan Permohonan Praperadilannya belum selesai maka perkara permohonan praperadilan tersebut gugur. Selanjutnya yang menjadi premisa minor adalah hukum in concreto yakni putusan nomor 3/Pid.Prap/2017/PN.Kfm yang dinyatakan gugur dalam putusan tersebut sehingga tidak memberikan kepastian hukum dan hal tersebut tercermin ketika putusan tersebut telah dinyatakan berkekuatan hukum tetap namun tidak dapat dieksekusi atau tidak dapat dilaksanakan. Dalam keadaan demikian, maka tentunya hal ini sangat tidak sejalan dengan apa yang diharapkan oleh Undang-Undang sebagaimana tertuang dalam pasal 6a KUHAP yang menyatakan bahwa "Jaksa adalah Pejabat yang diberi wewenang oleh Undang-Undang ini untuk bertindak sebagai Penuntut Umum serta melaksanakan Putusan Pengadilan yang telah memperoleh kekuatan hukum tetap". Selaku Eksekutor, Jaksa telah melakukan tugasnya dengan upaya mengeksekusi putusan praperadilan aquo secara terbuka/ dihadapan keluarga para tersangka dan penasehat hukumnya pasca putusan tersebut ditetapkan namun karena secara de facto Penahanan terhadap para tersangka tidak lagi menjadi wewenang Penyidik atau Penuntut Umum pada Kejaksaan Negeri Timor Tengah Utara, melainkan wewenangnya 
ada pada Pengadilan Tindak Pidana Korupsi pada Pengadilan Negeri Kupang, maka Kepala Rumah Tahanan Negara Kupang tidak berkenan untuk mengeluarkan para terdakwa dari Rumah Tahanan Negara Kupang terkait Praperadilan dimaksud.

Terhadap penjelasan diatas, penulis berpendapat bahwa jika badan pelaksana atau penegak hukum menetapkan suatu putusan dengan mengabaikan norma hukum positif yang berlaku maka akan menimbulkan suatu permasalahan yang baru, dimana para terdakwa dan atau keluarga menuntut agar segera dibebaskan dari tahanan, namun faktanya tidak dapat dilaksanakan. Hal inilah yang tidak memberikan kepastian hukum.

\section{KESIMPULAN}

Berdasarkan uraian pada bagian analisis, penulis berkesimpulan bahwa alasan tidak digugurkannya perkara praperadilan dengan No. 3/Pra.Pid/2017/Pn. Kfm ialah karena terdapat perbedaan penafsiran oleh hakim terhadap frasa atau norma yang tertuang dalam Putusan Makhamah Konstitusi No.102/PUU-XIII/2015 jo Pasal 82 ayat (1) huruf (d) Kitab UndangUndang Hukum Acara Pidana (KUHAP) yang seharusnya dimakna bahwa praperadilan dinyatakan gugur apabila pokok perkara telah dilimpahkan pada pengadilan serta telah dimulai siding pertama.

\section{Daftar Pustaka}

Afandi, Fachrizal. "Perbandingan Praktek Praperadilan Dan Pembentukan Hakim Pemeriksa Pendahuluan Dalam Peradilan Pidana Indonesia”, Jurnal Mimbar Hukum,Vol.16, No.1, 2016, 93-106: 96.

Amdani, Yusi. "Implikasi Penafsiran Undang-Undang oleh Hakim Praperadilan dalam Perkara Tindak Pidana Korupsi”, Jurnal Mimbar Hukum, Vol.27, No.3, 2015, 459471:461.

Barus, Zulfadli. “Analisis Filosofis tentang Peta Konseptual Penelitian Hukum Normatif dan Penelitian Hukum Sosiologis”, Jurnal Dinamika Hukum, Faculty of Law Universitas Jenderal Soedirman, Vol.13, No. 2, 2013, 307-318:311.

Djami, Arri. “Analisis Yuridis Terhadap Putusan Hakim Praperadilan Tentang Keabsahan Tindakan Penyitaan Oleh Penyidik Pegawai Negeri Sipil Kehutanan (Studi Kasus Putusan Praperadilan Pontianak dan Bengkayang) ", Jurnal Nestor Magister Hukum, Vol.2 , No.2, 2012, 1-18:2.

Djanggih, Hardianto dan Yusuf Saefuddin. "Pertimbangan Hakim Pada Putusan Praperadilan: Studi Putusan Nomor: 09/Pid.Pra/2016/Pn.Lwk Tentang Penghentian Penyidikan Tindak Pidana Politik Uang”, Jurnal Penelitian Hukum De Jure, Vol. 17, No. 3, 2017, 413-425:414.

Farezha, Wanda Rara, Eddy Rifai, Gunawan Jatmiko. “Analisis Putusan Hakim Praperadilan Dalam Perkara Tindak Pidana Korupsi (Studi Putusan Praperadilan Nomor 14/Pid. Pra/2016/PN.Tjk)”, Jurnal Poenale, Vol.5, No.3, 2017, 1-14:3.

Harahap Yahya. (2003). Pembahasan, Permasalahan dan Penerapan KUHAP, Jakarta: Sinar Grafika.

Hidayat, Maskur. "Pembaruan Hukum Terhadap Lembaga Praperadilan Melalui Putusan Pengadilan”, Jurnal Yuridika, Vol.30, No.3, 2015, 505-524:509 
Makhamah Agung Republik Indonesia, Putusan Pengadilan Negeri Kefamenanu Nomor 3/Pid. Prap/2017/PN.Kfm.

Marzuki, Peter Mahmud. (2005). Penelitian Hukum. Jakarta: Kencana Prenadia Group.

R, Soeparmono. (2003). Praperadilan dan Penggabungan Perkara Gugatan Ganti Kerugian dalam Kuhap. Bandung: CV. Mandar Maju.

Mulyadi,Lilik. (2007). Putusan Hakim dalam Hukum Acara Pidan., Bandung: PT. Citra Aditya Bakti.

Mulyani, Sri. "Penyelesaian Perkara Tindak Pidana Ringan menurut Undang-Undang dalam Perspektif Restoratif Justice”, Jurnal De Jure, Vol.16, No.3, 2016, 337-351:342.

Panggabean, Mutiara Kania. "Implementasi Putusan Mahkamah Konstitusi Nomor 102/ Puu-Xiii/2015 Mengenai Gugurnya Pemeriksaan Praperadilan (Studi Putusan Praperadilan Nomor 96/Pid.Prap/2017/PN.Jkt.Sel dan Putusan Praperadilan Nomor 133/Pid.Prap/2017/PN.Jkt.Sel)”, Jurnal Mahupiki, Vol.1, No.2, 2019, 1-36:6.

Satriya, Bambang. "Urgensi Integritas Penyelenggara Pemilihan Umum dalam Menegakkan Kedaulatan Rakyat”, Jurnal Etika dan Pemilu, Vol.3, No. 1, 2017, 9-20:10.

Siregar, Rahmad Efendy Al Amin. "Due Process Of Law dalam Sistem Peradilan Pidana di Indonesia dalam kaitannya dengan Perlindungan HAM", Jurnal Kajian Ilmu-Ilmu Keislaman, IAIN Padang Sidimpuan, Vol.1, No.1, 2015, 35-46:44.

Sujiono. "Implementasi Lembaga Praperadilan Untuk Perlindungan Hukum Hak-Hak Tersangka (Studi Kasus di Pengadilan Negeri Tenggarong”, Jurnal Arena Hukum, Vol.6, No.2, 2013, 272-289:274.

Suprapto, Maria Farida Indrati. (1998) Ilmu Perundang-Undangan, Yogyakarta:Kanisius.

Susak,Oktein Josephus. "Perspektif Keadilan Dan Kepastian Hukum Dalam Putusan Praperadilan Nomor: 04/Pid.Prap/2015/Pn.Jkt.Sel. Tahun 2015”, Jurnal Arena Hukum, Vol.9, No.1, 2016, 53-72:55.

Wewo, Jeremia Alexander, Kotan Y. Stefanus, and Umbu Lili Pekuwali. "Code Of Ethics Urgency In The Implementation Of General Election In Indonesia”, Jurnal Dinamika Hukum, Faculty Of Law Universitas Jenderal Soedirman, Vol.18, No.2, 2018, 194199:194.

Wilamarta, Misahardi dan Zulfadli Barus. "Manfaat Analisis Yuridis dan Sosiologis yang Bersifat Komplementer dalam Perjanjian Kredit untuk Meminimalisir Resiko Bank sebagai Kreditor”, Jurnal Hukum Yustisia, Vol 1, No.2, 2012, 151-168:154.

Wulandari, Sri. “Kajian tentang Praperadilan dalam Hukum Pidana”, Ejurnal Serat Acitya, Vol.4, No.3,2015, 1-14:1. 